\title{
Література:
}

1. Качуровський, I. В. Основи аналізу мовних форм. Стилістика. Фігури. Тропи, Світ, 2011. 86 с.

2. Ковалів, Ю. І. Поетичне мовлення, поетичний стиль, художній стиль. Художньо-белетристичний стиль, Академія, 2007. 320 с.

3. Науменко, Л. П. Основний курс перекладу 3 англійської на українську мову, Нова. Книга, 2016. 136 с.

4. Ткаченко, А.О. Мистецтво слова. Вступ до літературознавства, Наука, 1988. 448 c.

5. Dirven, René. Metonymy and Metaphor: Different Mental Strategies of Conceptualisation. Radden, 2003. 111 p.

DOI https://doi.org/10.30525/978-9934-26-073-5-2-34

\section{ПОНЯТТЯ АДЕКВАТНОСТІ \\ ТА ЕКВІВАЛЕНТНОСТІ ПЕРЕКЛАДУ РОСІЙСЬКИХ ДІЄПРИКМЕТНИКІВ ТА ДІЄПРИКМЕТНИКОВИХ ЗВОРОТІВ УКРАЇНСБКОЮ МОВОЮ}

\author{
Саїк А. В. \\ кандидат філологічних наук, дочент, \\ дочент кафедри філології та мовної комунікації \\ Начіонального технічного університету "Дніпровська політехніка» \\ м. Дніпро, Украӥна
}

Переклад як термін має полісемантичну природу, його найбільш розповсюджене і здебільшого узагальнююче значення пов'язують 3 процесом передачі значення слова, групи слів, речення або уривку з мови оригіналу на мову перекладу. Поняття «переклад» можна визначити так: заміна текстового матеріалу однісї мови (мови оригіналу) еквівалентним текстовим матеріалом іншої мови (мови перекладу) [6 с. 14-19].

Головною метою будь-якого перекладу - $\epsilon$ досягнення адекватності. Адекватність - це вичерпна передача смислового змісту оригіналу i повна функціонально-стилістична відповідність йому. Оскільки зрозуміло, що було б непогано, якби зміст оригіналу та перекладу були тотожними, то можна зробити висновок, що переклад має повністю зберігати зміст оригіналу: повноцінність перекладу означає вичерпну передачу смислового змісту оригіналу і повну функціонально-стилістичну відповідність йому [8, с. 45-47]. Але науковець Л.С. Бархударов 
вважає, що про повну відповідність можна говорити лише відносно, адже за його словами при перекладі уникнути втрат неможливо, тобто має місце неповна передача значень, які містить текст оригіналу. Виходячи 3 цього, дослідник робить закономірний висновок, що текст перекладу ніколи не може бути повним та абсолютним еквівалентом тексту оригіналу [2, с. 4951]. Схожої думки дотримується і Ю. Найда, за словами якої намагання досягти еквівалентності може призвести до значного відходу від оригіналу. Саме тут необхідно зазначити, що терміни «адекватність» і «еквівалентність» дещо відрізняються один від одного [7, с. 39-43].

Еквівалентність виступає основою комунікативної рівноцінності, наявність якої і робить текст перекладом.

Під поняттям еквівалентності перекладу розуміють передачу під час перекладу змісту оригіналу, який розглядається як сукупність інформації, що міститься в тексті, включаючи емотивні, стилістичні, образні, естетичні функції мовних одиниць. Таким чином, еквівалентність - поняття ширше, ніж «точність перекладу», під яким зазвичай розуміють лише збереження «предметно-логічного змісту» оригіналу. Інакше кажучи, норма еквівалентності означає вимогу максимальної орієнтованості на оригінал [7, с. 61-67].

Адекватний переклад $є$ за значенням еквівалентним, хоча ступінь смислової спільності між оригіналом та перекладом може бути різною. Найбільш повна еквівалентність (на рівні мовних знаків) означає максимально можливу наближеність змісту різномовних текстів. Еквівалентний переклад не завжди буде вважатись адекватним, через те, що він буде лише задовольняти вимогу смислової наближеності до оригіналу [6, с. 121-123].

Таким чином, якщо говорити про способи перекладу російських дієприкметників та дієприкметникових зворотів українською мовою, варто зазначити, що дієприкметник - це гібридна, міжчастиномовна одиниця, вона властива всім індоєвропейським мовам.

Характеризуючи дієприкметники російської мови у порівнянні 3 українською, виділяємо в російській мові чотири різновиди дієприкметників:

1. Дієприкметники пасивні минулого часу, утворені за допомогою суфіксів -н- і -m-, наприклад: рисованньй, разбитьй. Цим дієприкметникам відповідають аналогічні в українській мові: мальований, розбитий.

2. Дієприкметники, що мають суфікси -ущ-, -ющ-, -ащ-, -ящ-. Вони дійсного способу, активного стану, теперішнього часу, наприклад, 
несущий, читающий, дрожащий, красящий. Відповідників цим російським формам в українській мові немає. А деякі слова, що мають такі суфікси, перейшли або в прийменники, або в іменники, наприклад: тямущий, завидющий чоловік, загребущі руки, пропащуа сила - прикметники; трудящий - іменник.

3. Дієприкметники активного стану минулого часу із суфіксами - $u-$, ви-: несший, писавший. Деякі дієприкметники російської мови цього розряду можуть перекладатися так званими еловими формами, із суфіксом -л-, наприклад: замерзиий - замерзлий, умериий-вмерлий.

4. Дієприкметники пасивні, теперішнього часу з суфіксами -ом-, -ем-, -им- наприклад: ведомый самолет, изучаемая наука, любимое матерью дитя. Подібних дієприкметників українська мова не знає. Деякі слова 3 такими суфіксами перейшли в українській мові в розряд прикметників чи іменників, наприклад: знайомий, відомий, невгасимий, любимий.

Зазначимо, що загальновживаним способом перекладу дієприкметників є підрядні з'ясувальні речення із сполучними словами щзо та який. Наприклад, рисующий мальчик - хлопчик, щуо/який малює; вошедший человек - людина, щзо увійшла.

В українській мові в ролі активних дієприкметників теперішнього часу певний час вживалися ч-форми. У 20-30-х роках минулого століття побутувала тенденція вважати такі форми ненормативними. На сьогодні вони оцінюються неоднозначно, але більшість учених наголошують на обмеженості їх вживання, а то і на повній відмові від них. У науковотехнічних текстах подекуди трапляються такі приклади: кипляча вода, цุиркулююча кров і подібні. Але в художньому стилі ч-форми як дієприкметники заперечуються.

Цілком природньо, що перекладні словники, які розглядають i описують слово як окрему лексичну одиницю поза широким контекстом, рекомендують тільки найпростіший, найближчий за значенням відповідник, дають, так би мовити, лише відправну точку для творчої роботи перекладача. Словники неспроможні врахувати всі ті мовностилістичні нюанси, які виявляються в процесі перекладу, особливо перекладу художньої літератури.

Механічне, послідовне використання деякими перекладачами синтаксичної конструкції з який (що) показало, що цей спосіб перекладу не $є$ універсальним, що словникові рекомендації потрібно вміло варіювати $з$ іншими перекладацькими засобами - 3 тими, що не потрапили та й не могли потрапити до лексикографічних праць.

Відмітимо, що український дієприкметник уживається набагато рідше, ніж його російський еквівалент. Таким чином, наводиться 
синтаксична конструкція, що складається 3 відповідного дієслова та сполучника який або щзо і українського дієприкметника: отиветший який (що) відивів, відивілий, відквітлий; вимерший-який (що) вимер вимерлий. Якщо в українській мові дієприкметника еквівалентного російському не існує, подається тільки конструкція з який, щъо: вьющийся -який (що) в'ється, який (що) плететься; коксующийся - який (що) коксується; фильтруюшийся - який (що) фільтрується.

Саме цей спосіб перекладу привертав увагу вітчизняних науковців 3 теорії перекладу. Це питання порушив відомий український перекладач С.П. Ковганюк: «Не треба мати надто музикального слуху, - писав він, щоб почути, який це неприродній, неестетичний й ненормальний для української мови вислів. А їх у перекладній літературі (а часом і в оригінальній) безліч. Перекладені тільки цим способом дієприкметники спотворюють текст, виростають частими «пеньками» на рівній дорозі, $\mathrm{i}$ читач, що мав би йти легко, не помічаючи цієї дороги, спотикається на «що»-пеньках через кожні кілька кроків»[5, с. 124-129].

За допомогою синтаксичної конструкції, що складається з двох слів сполучника щџо, рідше який і зовсім рідко котрий та відповідного дієслова, найвдаліший російський вислів можна перекласти так, що українською мовою він втратить свою стрункість, органічність, милозвучність. «Нормальний, рівний російський вислів, - підкреслював С.П. Ковганюк, - під час перекладу перетворюється на кострубатий. Слово «щьо» наче розрубало його надвоє, загальмувало»[5, с. 131-135]. Речення $з$ такою конструкцією часто видається штучним, недовершеним. Про неприродність таких висловів свідчить хоча б те, що в оригінальній українській літературі (за поодинокими винятками) їх просто немає.

Отже, як свідчить досліджуваний матеріал, російська мова має розвинену систему дієприкметників на відміну від української мови. Тому під час роботи над перекладацькими трансформаціями ми звертаємося до різних способів перекладу дієприкметників, а саме: переклад відбувається прикметником, дієприкметником або описовою конструкцією (підрядним реченням).

Перекладацька еквівалентність як лінгвістичне поняття, що виражає певну спільність змісту оригіналу і перекладу, пов'язані із особливостями мов, що беруть участь у перекладацькому процесі.

\section{Література:}

1. Антоненко-Давидович Б. Д. Як ми говоримо. К. : Вид. дім «KM Academia», 1994. 254 c. 
2. Бархударов Л. С. Мова і переклад. М. : Міжнародні відносини. 1975. $235 \mathrm{c}$.

3. Зарицький M. С. Переклад: створення та редагування. K., 2004. 120 c.

4. Кінаш Б. М. Формування науково-технічних термінів 3 дієприкметниками. Львів : Вид-во Нац. ун-ту «Львівська політехніка», 2002. $36 \mathrm{c}$.

5. Ковганюк С. П. Практика перекладу. К., 1968. 274 с.

6. Комісаров В. Н. Лінгвістика перекладу. М. : Міжнародні відносини, $1980167 \mathrm{c.}$

7. Найда Ю. А. Процедура аналізу компонентної структури референційного значення. М., 1983. 120 с.

8. Федоров А. В. Основи загальної теорії перекладу. М. : ООО Філологія три, 2002. 416 с.

DOI https://doi.org/10.30525/978-9934-26-073-5-2-35

\title{
ПЕРЕКЛАДАЦЬКІ ТРАНСФОРМАЦІЇ ПРИ ВІДТВОРЕННІ ПОБУТУ ЯК МАРКЕРА СОЦАЛЬНОГО СТАТУСУ ПЕРСОНАЖА НА ОСНОВІ РОМАНУ ОСКАРА УАЛЬДА «ПОРТРЕТ ДОРІАНА ГРЕЯ»
}

\author{
Ситюк В. В. \\ студентка 5 курсу кафедри англійської філології і перекладу \\ Національного авіаційного університету \\ м. Київ, Украӥна
}

Перекладацькі трансформації є невід'ємною частиною перекладу усіх творів. Саме тому ця тема досі цікавить багатьох науковців та вчених, як вітчизняних так $\mathrm{i}$ зарубіжних. Вивчення питання застосування трансформацій у перекладі побуту як маркеру соціального статусу персонажів неодноразово розглядалося такими дослідниками як-от: О. Лукашевич, О. Удод, В. Коцур, Jr. Gregory, W. Stanford та ін. Однак не зважаючи на те, що переклад побуту аналізувався багатьма науковцями, шляхи його відтворення в епоху Вікторіанської Англії все ще знаходяться на периферії перекладознавства, що й обумовлює актуальність даного дослідження.

До маркерів побуду ми відносимо усі ті лексеми, які описують життя Вікторіанської Англії в деталях, які характерні для Англії. Дана епоха 